\title{
Community radio, democratic participation and the public sphere
}

\begin{abstract}
Community radio is unique when compared to its commercial and public service counterparts in that, as a non-profit activity, it is owned, managed and controlled by local communities, In theory therefore, community radio offers the potential for more broad-based participation in deliberation and debate within the public sphere engaging multiple voices and perspectives and contributing towards progressive social change. Drawing on a study of four community radio stations in Ireland within a framework drawn from the evolving work of Habermas and associated deliberative, social and media theorists, in this article we examine the extent to which this is the case in practice. We find that democratic participation is still not optimised within the four stations studied. We argue that the reasons for this lie in four main areas: a somewhat limited policy framework; a focus within training programmes on technical competencies over content; the weakness of linkages between stations and their local community groups; and the failure of the latter to understand the unique remit of community radio. The article draws lessons of specific interest to researchers and activists in these domains, as well as offering a framework to those interested in examining community media's contribution to the re-animation of the public sphere more broadly.
\end{abstract}

Keywords: Community radio, public sphere, Habermas, democratisation 
Given the scale of problems facing humanity and the failure of current mainstream media to initiate critical dialogue, could we envisage a time when community media would become more prominent, more mainstream, more effective in promoting alternative mindsets and behaviours? We can either acquiesce in global injustice, environmental destruction and economic terrorism, or we can join the struggle, be the voice of civil society in the efforts for justice, democracy and freedom.

Jack Byrne, Community media activist, (Byrne 2007, 28)

\section{Introduction}

Given the unique place held by community radio in the broader 'mediapolis' (Silverstone 2007: 31), the growth of interest and research in community radio over the past couple of decades is encouraging. In a first strand of research, studies on the organisational structures of stations and the regulation of community radio operations emphasised the uniqueness of the sector vis à vis commercial and public service broadcasting. These studies explored the contributions of community radio stations to the development and wellbeing of communities. For the most part, a consensus emerged that community radio contributed to its community by reducing isolation (Read and Hanson 2006); by encouraging a sense of place (Keough 2010); by fostering dialogue (Siemering 2000); by show-casing local culture (Meadows et al 2005) and by including marginalised groups (Barlow 1988; Sussman and Estes 2005; Baker 2007). The defining characteristic of community media also contrasted with commercial and public service outfits in their structures of community based ownership, control and financing. Moreover, community radio was understood to be different in its stated objectives - to move beyond traditional notions of a mere 'audience' to generate a sense of community, by providing information relevant to the needs of its members, by engaging members in discourse and by promoting 
democratic participation (Jankowski and Prehn, 2003). The core sense of community radio that emerged from this strain of research was that there was no impartial mass audience but rather only potential and actual broadcasters who constituted active participants in a community-owned and managed communication project.

The challenges this presentation of community media posed to theoretical frameworks generated what could be described as a second strand of research. Work in this latter vein demonstrated the failure of mainstream broadcasting to contribute to any kind of public sphere and contrasted this with the aspirations that underpinned community sector broadcasting. Studies in this genre include Stiegler (2009), which draws on Barber's model of 'strong democracy' to elucidate what small-scale public spheres might look like within the context of community radio within the US (Barber 1984, after Stiegler (2009: 50-51)). In a similar way, Meadows et al argue that, by providing communities with 'alterNative' ideas and assumptions (2005: 183), the community radio sector in Australia has extended the idea of the mainstream public sphere. Closer to home, in a detailed study of community radio in Ireland Day (2009) has developed an extremely useful framework which distinguishes between seven levels of participation as she argues that that participation - beyond mere programme production - is the key to the success of a community radio station. As the quote from Jack Byrne, one of Ireland's principle community media activists, at the beginning of this article indicates, for proponents and activists of community media in Ireland community radio is firmly situated at the nexus between democracy, the right to communicate within the public sphere, and local community development. A unifying problem, however, in this second generation of research is that the specific 
components of the public sphere, as theorised by Habermas and his followers, remain somewhat underdeveloped as they relate to community radio (see also Jankowski and Prehn 2003 and Day 2009 on this point). This article aims to engage in this debate by exploring how community radio in Ireland might be related to the ideas presented by Habermas and associated deliberative theorists. It explores whether or not community radio practitioners in Ireland see a role for their stations in diversifying and animating the public sphere, or indeed public spheres, or whether their aims and objectives lie elsewhere

\section{Community media and the public sphere}

Jürgen Habermas' The Structural Transformation of the Public Sphere (1962) proposed that the key social function of the media was the normalised ideal of publicity. Habermas contrasted the fora of an active, participative bourgeois public sphere - typified for instance in eighteenth century by the coffee house - with the commercialised and privatised public spheres of contemporary society, increasingly controlled by mainstream media elites. He argued that the commercialisation of the media in the 1800 s and 1900 s turned 'rational-critical' debate into 'cultural consumption' with the public sphere taking on 'feudal features' (1962/1989: 195) as powerful institutions of both market and state came to dominate. Habermas argued that active citizens had been transformed into passive consumers - of goods, services, politics and spectacle. The result was a 'decayed', 'manipulated' and 'manufactured' form of the public sphere (Habermas 1962/1989: 215-7). 
In his re-thinking of the Marxist concepts of base and superstructure within this communications framework, Habermas' distinction between the 'system' and the 'life-world' argued against both market and state intervention in the public sphere. Arguing that problems arise when the system - the powerful domains of market, state and organised interests within social life - invades or 'colonises' the practical domain of the everyday life-world - the civic domain / public sphere where shared common understandings develop within and across various social groups - Habermas argued for a defence of the life-world from the institutions of both state and market (Habermas 1987). Moreover, arguing that both the state and capitalism needed to be 'socially tamed', Habermas (1987: 363) envisaged that the shared understandings, views and perceptions formed within the life-world, at the periphery of political life, would feed upward into policy and decision-making within the system at the centre.

In Habermas' view, the 'colonisation' of the life-world by the system, most notably the colonisation of the media as a key institution within the life-world by the state and market, resulted in a crisis of modernity, of which the erosion or refeudalisation of the public sphere was a significant part. Following this bleak critique of modernity Habermas later offered an account of emancipatory possibility through his theory of communicative action. This proposed a normative model of rational-critical debate through which political emancipation could be achieved. In arguing that the 'selforganised public sphere must develop a prudent combination of power and selfrestraint that is needed to sensitise the self-steering mechanisms of the state and the economy' (1987: 365), Habermas proposed the public sphere as a site of rational critical deliberation, open and accessible to all citizens employing deliberative norms 
that are inclusive, reasoned and reflective, and aimed at reaching common understanding and consensus (Habermas 1987).

In his later, more optimistic, work, 'Between Facts and Norms', Habermas turned his attention to the actors who might animate such a public sphere. In this regard, he posited a key role for civil society organisations (CSOs) in mediating between private and public spheres, bringing issues, ideas and aspirations from the private sphere to the public and on upward towards administrative and legal policy and decisionmaking institutions. Positing a two-track theory of democracy in which traditional institutions of liberal democracy exist side by side and contend with a vibrant public sphere, Habermas argued that unconstrained communication within this public sphere is made possible by such CSOs which periodically renew the political debate and, acting as a bridge between this public sphere and liberal democratic institutions, force the official circuits of power within these institutions to be attentive and responsive to new issues arising at the periphery of the system.

However both the communicative norms and the role for CSOs in mediating between private and public spheres Habermas proposed have drawn considerable debate and critique from a wide range of theorists. In relation to the first issue, post-structuralists argue that Habermas delivers an overly rationalist conception of the public sphere, which fails to adequately theorise pluralism and power. Specifically, critics argue that the norms of rational discourse with their deliberative emphasis on communicative reason and consensus ignore the pluralist and inevitably conflictual 
nature of society (Mouffe 1996; 2005) and exclude individuals and groups for whom more emotive, less bounded and less rational forms of communication are the norm (Young 2000; 2003) thus reinforcing and reproducing existing exclusions and inequalities as powerful actors come to dominate the public sphere (Fraser 1992). In relation to Habermas' two-track democratic theory, criticisms centre around both its implicit abandonment of more radical democratic ideals and the normative role posited for CSOs. On the former, Seyla Benhabib (1997) argues that Habermas ignores 'democracy's discontent' $(1997,726)$. As she notes, $(1997,726)$ '...the dismantling of the welfare state by neoliberal governments on both sides of the Atlantic; the tremendous sense of apathy, cynicism, and disillusionment with the political process visible in so many democracies and as manifested in lower rates of voter turnout and civic membership; the eclipse of popular sovereignty through the rise of new financial, capital, and communications networks - are all missing from Habermas's account of democracy'. In her view, Habermas is merely tinkering around the edges of a flawed system rather than offering possibilities for its transformation. On the role attributed to CSOs within this process, critics raise the 'faction' problem common within traditional interest group politics - that of incomplete representation and self-serving behaviour on the part of CSOs as they either become co-opted into traditional institutions, therefore narrowing the scope of the public sphere or, as in traditional interest group politics, they represent the specific interests of their members, and not those of society more broadly (Fung 2003; see also Gaynor 2011 on this issue in Ireland). 
With respect to communicative norms, while Habermas is often presented in binary opposition to theorists who argue for a diversification of such norms, both parties have over time diversified their conceptualisations of the public sphere. Habermas has evolved towards a much more plural conception of public spheres (Brady 2004; Dahlberg 2005) and later contributors have modified the importance of a purely reason-centred consensus (Dryzek 2000). Deliberations in the public sphere are now understood to include a wide range of communication acts accommodating marginalised, disenfranchised groups (Young 2000, 2003; Karppinen et al. 2008). For many theorists, the ideals of alternatives and universal access appear largely compatible with deliberations within a healthy public sphere which is now seen to embody a wide range of communication acts, which encourage critique, understanding, contestation and accommodation alike. However, these accommodations relating to communicative norms notwithstanding, the problems associated CSOs mediating between private and public spheres remain.

Within these conceptualisations of the public sphere, at the heart of debates on the social functions of the media is the notion of 'publicity' - citizens' freedoms to express and publish opinion, the 'right to communicate' (Splichal, 2002, 11-17) or as Silverstone later called it 'publicness' (2007:29). Silverstone has argued for a highly pluralistic and fluid media sphere. As he notes, 'The media are both context and themselves contextualised. They both construct a world, and are constructed within and by that world. And of course the world is plural not singular' (Silverstone 2007:6). Silverstone further sets a challenge, whereby if the media do in fact 
constitute the world's 'publicness' it behoves us to interrogate what kind of 'publicness' this is, 'what its strengths and weaknesses are, what its consequences might be, what its responsibilities are, and what might be changed' (Silverstone, 2007:29). Whether understood through concepts of 'public sphere' (Habermas) 'publicity' (Splichal 2002) or 'publicness' (Sliverstone 2007) these ideas have come to be reflected in the ethos of community radio where participation and 'the right to communicate' is highlighted by key policy influencers (see AMARC ${ }^{1} 1994$ ) and practitioners (Byrne 2007; McGann 2007; Ruddy and Walshe 2007; Day 2009) alike. Issues of access and participation lie at the heart of community media ethos and practice. Not alone does community radio provide a news and information service relevant to the needs of the local community, it provides a service which is owned and controlled by this community, with content and production determined by the community itself. Democratic participation in the public sphere through community radio in theory therefore varies significantly from its commercial and public service broadcasting counterparts where public access to the airwaves is limited to written correspondence (letter, texts, emails, tweets), phone-ins, and invited guest spots.

It is apparent from the above discussion that if we are interested in opening up the public sphere, a range of complex issues present themselves. We need to think about who inhabits this space and who does not, how they do so and how they do not, and above all, how the space might be rendered more open and inclusive in the form envisaged by Habermas and his followers. In short, when thinking about the public

\footnotetext{
${ }^{1}$ The Association Mondiale des Radiodiffuseurs Communautaires (AMARC) / World Association of Community Radio Broadcasters is an international NGO serving the community radio movement. IT was founded in Montreal, Canada in 1983.
} 
sphere, we need to examine the structural issues of access, participation and communication, together with the agency of civic and state actors in this regard, addressing as we do so, some of the key questions emanating from the literature to date. This article examines the extent to which this ideal of publicness or publicity is fully embraced and enacted in the context of Irish community radio.

The article draws on an in-depth study of four community stations in Ireland ${ }^{2}$. These were selected to reflect a diversity in settings (two semi-rural; two urban across three provinces) and in focus (three have 'geographic community' licenses and one a 'community of interest' licence). All have obtained their licenses in the last 10 years ${ }^{3}$. The research sought to document and analyse the experiences, analyses and aspirations of a range of community radio practitioners on the role and potential of community radio within their communities. Research was carried out over a seven month period in 2010. This included an initial workshop at the $\mathrm{Craol}^{4}$ annual conference - an event which brings together community radio practitioners from the 22 stations operating across the country, and visits to the four participant stations where interviews were carried out with 25 staff and volunteers across the four stations. A further round of interviews was held with representatives of eight community groups and agencies in the four transmission areas to explore their links with the respective stations. The results outlined below highlight some elements of community radio which contribute towards a democratisation of the public sphere.

\footnotetext{
2 These are Liffey Sound FM; Life FM; Tipperary Mid-West and Ros FM. Of these, Life FM holds the 'community of interest' license, targeting a Christian community within its broadcast area.

${ }^{3}$ Although Tipperary MW has been on air, under different licensing arrangements, since 1980.

${ }^{4} \mathrm{Craol}$ is an umbrella group for community radio stations in Ireland. As well as advocating on behalf of the sector, it offers a range of training programmes and supports (interview Craol coordinator; see also www.craol.ie).
} 
However the results also uncover shortcomings in this regard, notably a failure to engage fully in a practice of social and political liberation as envisaged by theorists and proponents of community media (see Meadows et al 2005; Byrne 2007; Day 2009; Stiegler 2009). We begin with an overview of the four stations studied.

\section{Overview of the four stations}

Table 1 below provides a brief overview of the four stations examined.

Table 1: Overview of four stations

\begin{tabular}{|c|c|c|c|c|}
\hline $\begin{array}{c}\text { Station / } \\
\text { characteristics }\end{array}$ & Life FM & Liffey Sound FM & Ros FM & $\begin{array}{c}\text { Tipperary } \\
\text { West }\end{array}$ \\
\hline Established & $\begin{array}{l}\text { License awarded } \\
\text { in Sept 2006, on } \\
\text { air in March } \\
2008 .\end{array}$ & On air in 2006. & $\begin{array}{l}\text { License awarded } \\
\text { in } 2003 \text {, on air } \\
\text { since } 2005 \text {. }\end{array}$ & $\begin{array}{l}\text { Began as a pirate } \\
\text { station around } 1979 ; \\
\text { awarded commercial } \\
\text { license from } 1990- \\
\text { 2004; community } \\
\text { license since } 2004 \text {. }\end{array}$ \\
\hline Broadcast area & $\begin{array}{l}\text { Cork city } \\
\text { boundaries }\end{array}$ & $\begin{array}{l}10 \text { mile radius } \\
\text { around Lucan }\end{array}$ & $\begin{array}{l}5 \text { mile radius } \\
\text { around } \\
\text { Roscommon town }\end{array}$ & $\begin{array}{l}20 \text { mile radius } \\
\text { including } 7 \text { miles } \\
\text { around Tipperary town } \\
\text { and } 4 \text { miles around } \\
\text { Cashel town. }\end{array}$ \\
\hline No. of paid staff & $\begin{array}{l}4 \text { (a fifth staff } \\
\text { member - the } \\
\text { station manager - } \\
\text { is voluntary) }\end{array}$ & $\begin{array}{l}0 \text { (all staff are } \\
\text { voluntary) }\end{array}$ & $\begin{array}{l}3 \text { (1 full-time and } \\
4 \text { part-time) }\end{array}$ & $\begin{array}{l}12 \text { ( } 4 \text { full-time and } 8 \\
\text { part-time) }\end{array}$ \\
\hline No. of volunteers & $\begin{array}{l}60-80 \text { with } 30-40 \\
\text { broadcasting } \\
\text { weekly }\end{array}$ & $\begin{array}{l}150 \text { with } 72 \\
\text { broadcasting } \\
\text { weekly }\end{array}$ & $\begin{array}{l}>100 \text { with } 17-18 \\
\text { broadcasting } \\
\text { weekly }\end{array}$ & $\begin{array}{l}>100 \text { with } 51 \text { broad- } \\
\text { casting weekly }\end{array}$ \\
\hline On air & $\begin{array}{l}\text { Mon-Sunday } \\
\text { 7am- midnight, } \\
\text { with repeats } \\
\text { through the night }\end{array}$ & $\begin{array}{l}\text { Mon-Friday, } \\
\text { 5pm- midnight; } \\
\text { Sat/Sun, 8am- } \\
\text { mid- night }\end{array}$ & $\begin{array}{l}\text { Mon-Friday, } \\
2 \mathrm{pm}-9 \mathrm{pm}\end{array}$ & $\begin{array}{l}\text { Mon-Sunday, } 8 \text { am- } 12 \\
\text { midnight, with repeats } \\
\text { through the night }\end{array}$ \\
\hline $\begin{array}{l}\text { Estimated } \\
\text { listenership }\end{array}$ & 13,000 per week & 11,000 per week & 13,000 per week & 90,000 per week \\
\hline $\begin{array}{l}\text { Cost per year to } \\
\text { run and sources }\end{array}$ & $\begin{array}{l}\text { Euro 84,000 } \\
\text { - Membership / }\end{array}$ & $\begin{array}{l}\text { Euro } 35,000 \\
\text { - Fundraising }\end{array}$ & $\begin{array}{l}\text { Euro } 150,000 \\
\text { - Pobal }\end{array}$ & $\begin{array}{l}\text { Euro } 250,000 \\
\text { - Donations / }\end{array}$ \\
\hline
\end{tabular}




\begin{tabular}{|c|c|c|c|c|}
\hline $\begin{array}{l}\text { of finance } \\
\text { (figures provided } \\
\text { by station } \\
\text { managers) }\end{array}$ & $\begin{array}{l}\text { Donations } \\
\text { - Fundraising } \\
\text { - Advertising* } \\
\text { - BAI Sound \& } \\
\text { Vision scheme }\end{array}$ & $\begin{array}{l}\text { - BAI Sound \& } \\
\text { Vision scheme }\end{array}$ & - Fundraising & $\begin{array}{l}\text { Fundraising } \\
\text { - Advertising } \\
\text { - Fas** } \\
\text { - Grants } \\
\text { - Investments }\end{array}$ \\
\hline
\end{tabular}

*Under the terms of their licensing agreement all community radio stations are limited to 6 minutes advertising per hour of broadcasting.

** Funding for staff costs.

As the data in Table 1 outlines, all four stations are relatively 'new' stations, although Tipperary MW has been on air, under different licensing arrangements, since 1980. All broadcast within a relatively localised area around the station. Three of the stations have paid staff and in Liffey Sound all staff are voluntary. A number of staff within both Ros FM and Tipperary MW are part-time, with Tipperary MW employing a wide range of part-time staff with their hours varying from less than 3 hours per week to twenty hours a week.

All stations engage a high number of volunteers with between 20 and 75 broadcasting weekly. The level of participation of volunteers in broadcasting is largely a function of the number of hours the stations are on air per week (with two stations broadcasting 24 hours a day, 7 days a week) and the number of paid staff. The listenership for each station is difficult to ascertain as the nationally collated statistics only apply to commercial stations. However, independent surveys commissioned by each station estimate listenerships of over 11,000 each week, with Tipperary MW combining local census figures with a recent listenership survey to estimate an approximate listenership of 90,000 per week. 
As Table 1 also shows, the four stations differ significantly in the annual costs required to run the stations, as well as the sources of funding for the stations. Life FM is heavily dependent on fundraising, membership and donations to support the station and its staff, and the station has also succeeded in financing specific programming through the BAI Sound and Vision Scheme ${ }^{5}$. Liffey Sound obtains the majority of its revenue through fundraising and also has drawn on the BAI Sound and Vision Scheme for specific programming. Ros FM, in contrast, secures over 80 per cent of its overall costs through Pobal's Community Services Programme, with the balance coming from fundraising events held throughout the year. In contrast again, Tipperary MW secures 50 per cent of its costs from local advertising, with a further 32 per cent coming from fundraising events and donations. Grants account for 6 per cent of the station's revenue while investments make up a further 2 per cent, most notably two annual draws which bring in between $€ 55,000$ and $€ 60,000$ per annum. Tipperary MW also secures a significant proportion of its revenue from public schemes (Fás' Community Employment Scheme in 2009, Pobal's Community Services Programme in 2010) but does not include these in its overall station costs in its budgeting.

While a considerable degree of variation may be observed in the costs and make-up of the four stations, as the following section demonstrates, the views of those involved in

\footnotetext{
5 The BAI's Sound and Vision Scheme is a funding scheme for the production of programming in the areas of Irish culture, heritage and experience and adult literacy - see http://www.bai.ie/index.php/funding-sectoral-support/sound-vision/.
} 
relation to the distinctive character and contributions of community radio overlap significantly.

\section{The Public Sphere and Community Radio}

The four community stations examined subscribe to some of the actions required to facilitate a healthy public sphere. As set out in further detail below, they do so by providing a localised and relevant information service for the community; by providing training for volunteers to participate in the community radio project; and by building a sense of shared community through media activism. Irish practitioners' views of the project of community radio very much tallies with the public sphere theoretical ideals of participation, access and open communication as set out in the literature. However, a key dimension of activism required to democratise the public sphere has not been adopted by practitioners. Stations do not explicitly identify a role in the progressive development of the public sphere, nor did they see a role for radio stations as channels of social and political activity or change. Moreover, for community groups within the stations' catchment areas, the service aspect of their stations overrides its process function. In other words, community actors engage with the 'lower' level forms of participation offered by the stations, rather than the 'higher' levels of direct control and access to the airwaves advocated in the theoretical frameworks that advocate a central role for community media in the democratisation of the public sphere (see for example, Day 2009; and for an adaptation of this Gaynor and O'Brien 2010). In short, the stations tend to work 'for' rather than 'with' their communities, and the information and publicity service approach dominates any more radical or transformative political end of democratising the public sphere. Therefore, 
the type of 'publicness' created by the stations examined, as understood by their practitioners, does not aspire to radical transformative ends. We go on to discuss in more detail the three principle ways in which local stations subscribe to these lower levels of participation.

\section{Information in the community}

One key service offered by community radio is its news and information service, which tends to be localised to meet community requirements. This information service is most appropriately described as very broad ranging and highly inclusive of all manner of issues submitted to the stations. This activity also includes issues such as directly highlighting citizen's information services and referring listeners to appropriate public service agencies. The on air information facility is important to listeners specifically and particularly because it is customised to their needs and accessible to them at all times. One station in particular sees its duty to inform the public in a broader context. It is particularly focused on its remit to educate and inform about disability. As the station manager puts it:

We're the only community station that has a disability ethos written into its contract with the Broadcasting Authority of Ireland. We're very proud to be able to deliver an informative view about issues pertaining to disability, to allow volunteers with disability to come in work with us here, to present shows, to have community notice-boards and to have programming dealing with topics pertaining to disability.

(Community station manager, site B)

Community radio provides an information service that is of benefit to communities because it both addresses educational issues for minority groups and because it retains 
an open-access policy on disseminating information which is customised to community-level needs. On both counts these agendas are largely unaddressed by any other local or national media service.

Community groups interviewed about the importance of community radio also highlighted the valuable information function. Stations examined are generally very happy to publicise the activities of community groups. They frequently interview people involved in community projects and, from time to time, they broadcast live from various community based locations. The centrality of the impact of the information function for the community groups is undisputed in any of the catchment areas of each of the four stations examined. The community groups interviewed named a number of different outcomes that arose from their community station's willingness to openly and freely air information. Through raising awareness of the existence and activities of community groups, one radio station claims to have led to an increase in the number of people availing of the services these groups. Similarly, in another community centre which caters to 38 groups or over 130,000 people in the immediate area, the centre coordinator views its community radio service as particularly important in getting information to people. Echoing many other commentators, the community centre's coordinator comments that the larger commercial stations remain almost entirely disinterested in the activity or work of small community groups. By contrast community radio has been very supportive of the centre's work, and particularly so with regard to publicising this. 'They have room for us to get our message across $[\ldots]$ they are a vital link for the community to sit down and listen to the community' (community centre manager, site A). Another 
large community development centre, which has over 50 staff, also makes extensive use of its station to advertise its events and training. One staff member who has been interviewed at various points on her local station notes that, when they organise and run local community events, 'approximately 60 percent of people hear about our events through the station' (community centre representative, site C). Thus, we may conclude that community stations are certainly making a strong contribution to one core dimension of the public sphere. As the following section demonstrates, stations are also, through their training programmes, making significant inroads in increasing access to the communications infrastructure.

\section{Training for democratic media participation}

As well as the informational contribution that community stations make to promoting a healthy public sphere, another way in which the community stations studied contribute to democratising the public sphere is by promoting broad-based community access to the airwaves through their training programmes. Volunteers are trained in the practical and production skills required to make radio programmes. They go on to gain invaluable on-air experience which allows them to continually upskill. They also develop personal and media production skills through their work at the community station. Although training programmes vary across the four stations, typically training provision initially involves socialisation into the workplace within the station. This usually involves an informal meeting with the station manager to discuss details of the areas that are of interest to volunteers and their availability to participate in various station activities. This initiation then progresses to volunteers 
performing voice tests for on-air work or alternatively finding a role that fulfils their specific individual needs and capabilities. The training is generally informal, on-going and multifaceted, with everything from researching, producing, editing and technical skills covered.

The outcome of this training for participants varies from facilitating entry into professional broadcasting work to more process-oriented type of benefits such as facilitating people in discovering new capacities and expanding their range of social skills. Volunteers and participants have gained insights and skills in the production and creative capacities required to make radio programmes, either by producing programmes themselves or simply by participating in them on-air. The training freely offered and received at the station is invaluable in progressing the social and production skills of participants. It facilitates them in up-skilling technically, it increases their confidence in their production abilities and it provides a supportive work-environment in which to further their interest and participation in community radio. The training remit undertaken by the community radio stations undoubtedly contributes to encouraging people to access the airwaves and, as such, it directly contributes to a democratisation of the public sphere. In addition to the information exchange and encouragement of media participation that community stations make, all participants in the community radio stations studied also note that their media work facilitates local people in engaging with the broader community and, in this way, counteracts isolation and generates a sense of belonging and participation in a shared public sphere amongst the wider community. 


\section{Building a Community through media}

The stations researched all make an effort to engage at some level with community groups in their catchment areas. Research participants consistently highlighted the emphasis that stations place on moving beyond a purely informational role to building linkages and networks between and across different groups and individuals. 'They frequently make very intentional efforts to move outside the physical confines of their studios in order to interact with communities at particular events. The station comes to events and broadcasts these.' (community centre representative, site D). 'We get out as often as possible, we work very hard on that'. (community station volunteer, site B). The stations are very open to promoting community events on air and they are conscious of creating connections for networks of community groups to engage with each other as well as to connect to their client base through the medium of radio. They observe that these networks are generated in part by other organisational connections held by the stations' participants. 'With 100 plus volunteers, each one of them is involved in at least one other organisation. So if something happens, they're onto us' (community radio volunteer, site A). As a presenter on one station commented on the impact of community radio for community groups in his area,

The big benefit is that they have something they know they can access [local community groups], and they can build relationships and channel their information. A lot of community groups are connected to one another, so we're becoming part of the network. If we can give them a hand, we can benefit the community.

(community radio volunteer, site D)

Community development activists interviewed for the research generally agree that 
the stations contribute to increased community participation. One respondent highlights the service provided by the station to people with disability in the town and its surrounds, offering them work experience and teaching them new skills, which increases their participation in the community. 'The station develops its own sense of independence $[\ldots]$ it delivers real tangible outcomes (community centre representative, site A)'. The other area she identifies as an important achievement of the station is its work with smaller groups and communities from ethnic minorities, noting that the station 'gets people involved who otherwise wouldn't be involved [...] they try to include the most isolated in the station' (community centre representative, site A). Another radio station has links to a variety of formal community groups in its area, in particular with a community centre in the local town which offers rehabilitative training, sheltered work, employment advice, and a residential service to people with intellectual disabilities. The station is a favourite of residents and clients and is played all day in the centre. A number of the centres' residents have visited the station and staff and report that volunteers have taken the time to sit and chat with the visitors. Many interviewees in this station's catchment area highlighted the local news service (community diary), the obituaries and religious service broadcasting on Sunday as being extremely important in giving those who may be more isolated in the community a sense of identification with and belonging to the community at a mediated if not a physical level.

In this way, station volunteers and staff actively seek to include a wide range of local community groups in their programming and to connect community groups through participation in their radio stations. As a volunteer with one station succinctly puts it, 'community radio is about a community speaking to itself and giving people that 
chance to participate, to be part of it and shape their own community' (community radio volunteer, site $\mathrm{B})$. In another station the manager emphasises that creating linkages is one of the station's main tasks. The manager, staff and volunteers interviewed within this station explicitly aspire to link community groups and to get the station more widely known in the area. One of the principle ways this is achieved is via mobile broadcasts. In this regard, resources are an issue. As one of the voluntary staff in the station notes, 'we'd like to do more of going out to particular areas [...] I'd like to see more community centres getting involved but the problem is resources' (community radio volunteer, site A). Despite the challenges raised by under-resourcing, one commentator strongly argues that, nonetheless, the role of community radio stations is to facilitate the community in dialogue by bringing people into the station to participate in programmes, by ensuring that this constitutes a positive experience for participants and that, essentially community radio should not mediate people or seek to explain people to its listeners. Rather it should provide the technical facility for people to tell their own stories. As another interviewee put it 'Community media can bring all these activists together, sharing their experiences and information, and building on it. It's a synergy of information that's there. And this again is an entirely different form of media where it's really about information sharing' (community radio volunteer, site C).

This sense of creating connections and building local community through community radio also exists in the sense of a community 'within' the stations which ensures access to the public sphere for groups that would have traditionally been very marginalised. These internal communities of practitioners share a common interest in 
community radio and, through their interactions in the station, they have created social networks that are inclusive of people who may otherwise have been quite marginalised in their social worlds. A presenter from one station notes the weight given by the station community to involving volunteers and ensuring that they feel comfortable within the station. 'We have volunteers where this is like a home, it's a community, the people that come in, they feel like they belong here' (community radio volunteer, site B). As a community with a shared interest which is inclusive of all volunteers, community radio provides a distinct benefit to those that participate by constituting a 'community within' the radio station while also building and consolidating the wider community by fostering connections and networks.

\section{Democratising the Public Sphere}

While community radio activists subscribe closely to many of the objectives of a democratic public sphere as outlined within the literature - these being broad-based participation, open access and the exchange of information, in failing to act as a channel for more radical social and political transformative purposes, they fall short in engaging with the purpose of this democratisation as envisaged by public sphere theorists. The stations studied act instead in a more limited capacity, mostly to facilitate groups in publicising issues, agencies and events. This raises the obvious question of why it is that Irish community radio stations do not adopt a more overt political function of reclaiming the public sphere from its colonisation by the state and market? 
The remainder of this article argues that this is the case because of certain characteristics of Irish community broadcasting. These include the policy framework that underpins it, its historical tradition of local, commercial and pirate radio provision; and the emphasis on technical production skills over content. Moreover, this situation is not alleviated by community development groups who, in the catchment areas studied, are failing to engage with community stations in a political sense. As they have not shared their own organisational agendas for social change and emancipation, their community stations do not explicitly raise debate and discussion in these areas.

Community radio activists interviewed do not generally see their work as central to the task of reclaiming the media as a space within which to discuss possibilities for social change and empowerment. Research participants do however identify a role for community radio in promoting democratic communication, in so far as the stations studied all recognise the importance of promoting ideas and issues that are important to their communities. But this idea of the station 'giving voice' to those who might otherwise remain silent is limited to a sense of agendas being determined by listeners, rather than a more radical political interpretation of giving power to the marginalised or disenfranchised or countering the colonisation of the airwaves by state and market. While community radio certainly serves as a support in publicising community groups' work and services, it differs little from local commercial radio in this regard as it does not generally act as a portal for the voices of community group members. Community group members have rarely considered producing their own programmes 
or of using their local community stations to drive agendas for public debate. The level of engagement between stations and wider community groups remains limited to the lower level participation which is similar to that offered by local commercial stations rather than at a higher end of empowering community groups to direct the activities and content of the station. The issue of political empowerment and engagement is simply not on the agenda for either radio or community group activists. When asked about the station's role in promoting debate on issues relating to marginalisation and disadvantage in the area, one community group's representative notes that 'on the whole, the station does not go in for controversial issues [...] It's a safe pair of hands, therefore people are not alienated, and that's alright' (community centre representative, site A).

Reflecting further on their work with their local stations, community development activists acknowledge that they should use their stations more by working with people in local community groups to put together their own programmes. While staff within community centres feel that their stations are open to this, they also feel that the impetus and the large amount of time and energy required for this would have to come from themselves and that 'this would be a huge thing' (community centre representative, site D). While their station lacks this level of pro-activity, a community activist in its catchment area notes that it nonetheless is 'terribly supportive of community activity with a huge loyalty from the community [...] We'd miss them terribly if they were gone and, without them, the place would be significantly poorer' (community centre representative, site D). This said, essentially the main purpose that community radio serves for local community groups is to act as 
a publicity channel for these groups and their activities rather than as forums for political discussion or as agents of political empowerment. The democratic nature of communication is clearly articulated as a positive and beneficial aspect of community radio but the objective of advocating for social and political change or acting as a channel for community education in the name of social justice and socioeconomic development or of reclaiming media from state and commercial interests (Barlow, 1988) are not articulated as central to the community radio agenda of the four stations studied.

\section{Explaining the absence of political objectives and benefits}

The absence of an explicitly transformative remit for the community radio stations, however expressed, may be explained by a combination of the historical evolution of community radio in Ireland, which has overlapped and intersected with the emergence of local commercial stations; the training focus amongst community stations, which disproportionately focuses on practical broadcasting issues rather than community activism; and Ireland's broadcasting policy for the sector, which does not explicitly adopt AMARC's political objectives. With regard to the latter, community radio in Ireland has always had a very close relationship with the regulator, the Broadcasting Authority of Ireland (BAI) ${ }^{6}$. In fact community radio emerged from a pilot-project established in 1994 by the national broadcasting regulator, the BCI. As part of the support structures put in place, the BCI adopted part of the AMARC Community Radio Charter for Europe (1994) as a statement of the objectives community stations

\footnotetext{
${ }^{6}$ Formerly Broadcasting Commission of Ireland (BCI)
} 
should aim to achieve. An initial policy document defined community radio as characterised by a not-for-profit ownership where membership, management, operation and programming were primarily undertaken by members of the community at large (BCI, 2001: 3). Stations included in the community broadcasting strand were expected to 'promote and support active participation by this community at all levels in the operation; [and] to operate in a manner which is in keeping with the ethos or value system which underpins community activity' (BCI, 2001: 3).

More recently, community radio in Ireland has become bound by the 2009 Broadcasting Act. This has altered the definition of community radio to include a provision on 'social benefit'. As the Act notes, 'Programme material in pursuance of the contract will be effected with the sole objective of - (i) specifically addressing the interests of, and seeking to provide a social benefit to, the community concerned' (Stationery Office, 2009). Ultimately the objective of community radio practitioners in Ireland as set out by the BAI is to meet the ideal of generating social benefits for communities. However, the more political directive contained in the AMARC charter whereby community radio 'responds to the needs of the community which it serves and contributes to its development in a progressive manner, promoting social change' (AMARC, 1994: 1) is absent from the Irish policy framework and, in part, explains the lack of political emphasis on social change evident in the operation of community radio in Ireland. 
Historically, unlike in a number of other countries where community radio advocates espouse a more radical political agenda, the boundaries between commercial and community radio in Ireland have been very fluid and blurred. In Ireland, community radio has been unavoidably influenced by the domination of the pirate commercial stations that developed in tandem with it. In the 1970s and the 1980s, between 70 and 80 commercial, music-driven, pirate stations operated on air in Ireland (BCI, 2006). The distinction between these often small-scale local commercial stations and community radio was not always apparent, even to broadcasters within these stations, with both entities frequently using the word 'community' in their names.

A further element is the absence of an explicitly politically-oriented curriculum in the training of community radio participants as undertaken by the four stations studied and their umbrella association CRAOL. This training tends to emphasise the development of broadcasting-related skills rather than focusing on the more explicitly political remit of community radio. This has resulted in a low level of awareness of community radio's political agenda amongst the practitioners interviewed and consequently less evidence of or demand for changes to the status quo or overall orientation of community radio in Ireland.

On the community development side, community groups in the stations' catchment areas do not articulate any understanding of community radio as a social or political resource. Instead they view it solely as a publicity conduit and they fail to understand the political potential of community radio to address any broader transformative 
agenda. Community groups clearly view their local community stations more as a portal for information or training for the community rather than as a means of providing a radically different form of media engagement. The failure of community groups to understand and engage with the transformative capacities of community radio reduces the emancipatory community radio project in Ireland to a publicity 'service' for community groups, with particular consequences for both community empowerment and the public sphere within which community radio risks becoming 'less distinguishable from mainstream media' (Robinson, 1997: 17).

These findings resonate strongly with those of Rosemary Day who, in a detailed study of participation within six community radio stations, concludes, in a somewhat similar vein, that although

...community radio provides a real opportunity to act on the normative theory suggested, among others, by Enzensberger and Habermas [and that] Irish community radio stations operate in emancipatory and participative ways, enabling people to exercise their right to communication... the full and radical potential expected of these ways of broadcasting cannot be actualised as long as the majority of participants in those stations are unaware of the political and social implications of their operations.

(Day 2009, 119)

While Day attributes this lack of awareness to a need for more training within stations, we suggest that it is perhaps the content and focus of the training (focusing on technical aspects of programming and broadcasting rather than its more normative and political agenda) rather than the amount per se. We also propose a second explanatory factor which exemplifies some of the criticisms of Habermas's more optimistic 'Between Facts and Norms'. This is the implicit depoliticisation of CSOs and community groups themselves. As we argue in detail elsewhere (see Gaynor and 
O'Brien 2012), this is a consequence of Ireland's experiments with 'third way governance' and, as predicted by Habermas's critics, has resulted in a deradicalisation and effective co-option of some community groups.

\section{Conclusion}

In this article, which draws on a detailed study of four community radio stations, we have highlighted a number of elements of community radio which contribute towards a democratisation of the public sphere as envisaged by Habermas and his followers. However, we have argued that democratic participation is still not optimised within the community media sector in that its discourse remains limited to local news reporting and information provision rather than targeting more radical, and arguably divisive, issues which would, as advocated by AMARC and other commentators, promote social change. This, we have argued, is the case largely because of the apolitical leanings of Irish policy framework; historical traditions which blur the distinction between public and commercial broadcasters at local levels; the somewhat limited scope of community radio training programmes in stations themselves; the weakness of linkages between stations and community groups; and the failure of the latter to understand the unique remit of community radio. The article draws lessons of specific interest to researchers and activists in these domains, as well as offering a framework of use to community radio researchers interested in examining the sector's contribution to the democratisation and the re-animation of the public sphere more broadly. 


\section{References}

AMARC. 1994. 'AMARC Europe Charter', http://www.amarc.org, accessed April 2013.

Baker, S. 2007. 'Young People and Community Radio in the Northern Region of Adelaide, South Australia', Popular Music and Society 30(5): 575-590.

Barlow, W. 1988. 'Community radio in the U.S.: The struggle for a democratic medium', Media, Culture and Society 10(1): 81-105.

Benhabib, S. 'Review of "Between Facts and Norms", American Political Science Review 91(3): 725-726.

Brady, J. S. 2004. 'Assessing the Agonistic Critiques of Jürgen Habermas', Theory of the Public Sphere, Philosophy and Social Criticism 30(3): 331-354.

Broadcasting Commission of Ireland. 2001. BCI Policy on Community radio Broadcasting, Dublin: BCI.

Broadcasting Commission of Ireland. 2006. FAQs About Us, History of the BCI available at http://www.bci.ie/faqs/faq_about_history.html, accessed 19 May 2010.

Byrne, J. 2007. 'If Community Radio is the Answer... What is the Question?: The Birth of Community Radio in Ireland, 1975-1995', pp. 11-28 in R. Day (ed.), Bicycle Highway: Celebrating Community Radio in Ireland. Dublin: Liffey Press.

Dahlberg, L. 2005. 'The Habermasian Public Sphere: Taking Difference Seriously?', Theory and Society 34(2): 111-136.

Day, R. 2009. Community Radio in Ireland: Participation and Multiflows of Communication, New Jersey: Hampton Press.

Dryzek, J. 2000. Deliberative Democracy and Beyond: Liberals, Critics, Contestations, Oxford: Oxford University Press.

Fraser, N. 1992. 'Rethinking the Public Sphere: A Contribution to the Critique of Actually Existing Democracy', pp. 109-142 in C. Calhoun (ed.), Habermas and the Public Sphere. Cambridge MA: MIT Press.

Fung, A. 2003. 'Associations and Democracy: Between Theories, Hopes and Realities', Annual Review of Sociology 29(1): 515-539.

Gaynor, N. and A. O'Brien. 2010. Drivers of Change? Community Radio in Ireland. Dublin: Broadcasting Authority of Ireland.

Gaynor, N. and A. O'Brien. 2012. "'Because it all begins with Talk": Community Radio as a Vital Element in Community Development', Community Development Journal 47(3): 436-447.

Gaynor, N. 2011. 'Associations, Deliberation and Democracy: The Case of Ireland's Social Partnership', Politics and Society 39(4): 497-520. 
Habermas, J. 1987. Theory of Communicative Action: Volume 2. Boston: Beacon Press.

Habermas, J. 1989. The Structural Transformation of the Public Sphere: An Enquiry into a Category of Bourgeois Society. Cambridge, Mass: MIT Press.

Habermas, J. 1996. Between Facts and Norms: Contributions to a Discourse Theory of Law and Democracy. Cambridge, Mass: MIT Press.

Jankowski, N.W. and O. Prehn. 2003. Community Media in the Information Age: Perspectives and Prospects. Cresskill, NJ: Hampton Press.

Karppinen, K., M. Hallvard and S. Jakob. 2008. 'Habermas, Mouffe and Political Communication: A Case for Theoretical Eclecticism', Javnost - The Public 15(3): 522.

Keogh, S.B. 2010. 'The importance of place in community radio broadcasting: a case study of WDVX, Knoxville, Tennessee', Journal of Cultural Geography 27(1): 7798.

McGann, N. 2007. 'Women in Irish Community Radio', pp. 89-104 in R. Day (ed.), Bicycle Highway: Celebrating Community Radio in Ireland. Dublin: Liffey Press.

Meadows, M., S. Forde, J. Ewart and K. Foxwell. 2005. 'Creating an Austrailian community public sphere: the role of community radio' The Radio Journal International Studies in Broadcast and Audio Media 3(3): 171-87.

Mouffe, C. 1996. 'Democracy, Power and the Political', pp. 245-256 in S. Benhabib (ed.), Democracy and Difference, New Jersey: Princeton University Press.

Mouffe, C. 2005. On the Political. London and New York: Routledge.

Read, M. and R.E. Hanson. 2006. 'Back to the Future: Allegheny Mountain Radio and Localism in West Virginia Community Radio' Journal of Radio Studies, 13(2): 214-231.

Robinson, E. 1997. 'Flagship faces rough waters: US community radio in crisis', Interadio, 8(1): 17.

Ruddy, M. and P. Walshe. 2007. 'Dialogue not Monologue: Connemara Community Radio. pp. 179-200 in R. Day (ed.), Bicycle Highway: Celebrating Community Radio in Ireland. Dublin: Liffey Press.

Siemering, W. 2000. 'Radio, Democracy and Development: Evolving Models of Community Radio' Journal of Radio Studies 7(2): 373-378.

Silverstone, R. 2007. Media and Morality: on the rise of the mediapolis, Cambridge: Polity Press.

Splichal, S. 2002. 'The Principle of Publicity, public use of reason and social control', Media, Culture and Society 24(1): 5- 26. 
Stationery Office. 2009. Pt.6 S.72 [No. 18.] [2009.] Broadcasting Act 2009, Dublin: Stationery Office.

Stiegler, Z. 2009. 'Conceptualising the Small-scale Public Sphere', Javnost - The Public. 16(2): 41-60.

Sussman, G. and J.R. Estes. 2005. 'KBOO Community Radio: Organizing Portland's Disorderly Possibilities', Journal of Radio Studies, 12(2): 223-239.

Young, I.M. 2000. Inclusion and Democracy. Oxford: Oxford University Press.

Young, I.M. .2003. 'Activist Challenges to Deliberative Democracy', pp. 102-120 in J. Fishkin and P. Laslett (eds.), Debating Deliberative Democracy, Malden MA: Wiley-Blackwell 